\title{
AN INVESTIGATION INTO THE APPLICATION OF MAINTENANCE MANAGEMENT CONCEPT BASED ON RELIABILITY CENTERED MAINTENANCE OF TNI-AL FLEET (CASE STUDY OF CORVETTE / PARCHIM CLASS)
}

\author{
Yanif D.K. ${ }^{\ddagger}$ dan Iman T.D.
}

\begin{abstract}
ABSTRAK
Sebagian besar kapal-kapal perang TNI AL khususnya jenis parchim telah memiliki usia pakai lebih daripada dua puluh tahun. Secara intuitif dapat disimpulkan bahwa laju kerusakan dari sistem penggerak motor diesel yang telah terpasang berada di dalam periode wear-out dari kurva bathtub. Paper ini dimaksudkan untuk memperoleh dan membuktikan pola laju kerusakan dan tingkat resiko dari sistem penggerak motor diesel yang terpasang pada kapal-kapal KRI jenis parchim. Fungsi laju kerusakan dari masing-masing sistem penggerak motor diesel yang terpasang diperoleh berdasarkan distribusi yang paling sesuai untuk mewakili failure mode yang ada. Sedangkan tingkat resiko ditentukan dengan risk matrix. Weibull++ 4, sebuah perangkat lunak keandalan yang umum dipakai, digunakan untuk memperoleh parameter-parameter yang sesuai untuk masing-masing distribusi.
\end{abstract}

Kata kunci: kurva bathtub, laju kerusakan, tingkat resiko, failure mode, sistem penggerak motor diesel.

\section{ABSTRACT}

The majority of TNI-AL war-ships, particularly of parchim class, are old and have been used for more than twenty years. It can be said, intuitively, that rate of degradation of diesel engine system lies in the wear-out period of a bathtub curve. The present paper is aimed to obtain and prove degradation pattern rate and level of risk from diesel engine system installed in KRI fleet of parchim class. Function of degradation rate of each diesel engine system is obtained from the most suitable distribution represent failure mode. Whilst, level of risk is determine with risk matrix. Weibull +4 , a reliability software, was used to obtain parameters fit to each distribution.

Keywords: bathtub curve, degradation rate, level of risk, failure mode, diesel engine system.

\section{PENDAHULUAN}

Sebagai sebuah negara kepulauan yang memiliki luas laut lebih dari duapertiga dari luas daratan, Indonesia memerlukan kekuatan armada laut khususnya kapal-kapal perang untuk menjaga kedaulatan wilayahnya dari ancaman dan gangguan pihak-pihak tertentu maupun untuk menjaga kelancaran transportasi laut yang menggunakan jalur-jalur pelayaran yang ada. Kekuatan kapal-kapal perang tersebut harus didukung dengan kemampuan operasi yang tinggi dan handal disetiap kondisi operasinya. Namun, kebanyakan kapal-kapal perang tersebut merupakan kapal-kapal bekas yang diimpor dari negara-negara lain seperti: Jerman, Belanda, Rusia, Jepang, dan Korea. Sekalipun pemerintah dalam hal ini TNI AL telah banyak membangun kapal-kapal baru untuk jenis kapal patroli (FPB) namun kemampuan kapal-kapal patroli tersebut terbatas hanya pada daerah-daerah pantai dan dengan kecepatan operasi yang terbatas pula waktunya untuk digunakan. Disamping itu, keterbatasan dana yang dimiliki oleh TNI AL memaksa pembelian kapal-kapal bekas merupakan suatu keharusan. Kebanyakan dari kapal-kapal tersebut dibangun sekitar tahun 70an sehingga akibatnya kebanyakan dari sistem penggerak motor diesel yang terpasang telah sangat tua dan diperlukan repowering. Dengan kondisi yang demikian maka diperlukan suatu organisasi dan aktivitas pemeliharaan yang efektif terhadap kapal-kapal yang dimiliki oleh TNI AL.

Paper ini mendiskusikan hasil-hasil dari analisis pola kerusakan berdasarkan failure modenya terhadap sistem penggerak motor diesel yang terpasang di keenam belas kapal perang KRI jenis parchim. Agar data-data kerusakan dapat dikategorikan kedalam salah satu diantara ketiga region dari kurva bathtub maka data-data yang dikumpulkan adalah datadata yang paling tidak berada pada interval satu siklus operasi lengkap yakni setidaknya berada pada interval dua overhaul. Analisis dilakukan dengan membandingkan beberapa karakteristik antara sistem penggerak motor diesel. Karakteristik-karakteristik yang dibandingkan adalah jumlah kegiatan perawatan yang dilakukan dan frekuensi perawatan dari masing-masing sistem penggerak motor diesel.

Pemodelan masing-masing failure mode dari setiap kerusakan fungsional untuk masingmasing sistem penggerak motor diesel juga dilakukan. Variabel acak merupakan variabel penting didalam analisis kerusakan. Time to failure ditentukan sebagai variabel acak dan disimbolkan dengan TTF.

\footnotetext{
* Mahasiswa S3 Program Pasca Sarjana Teknik Kelautan, FTK ITS

E-mail: yanif_dk@yahoo.com

$\S$ Mahasiswa S1 Jurusan Teknik Sistem Perkapalan, FTK ITS
} 


\section{MODEL KERUSAKAN}

Sebuah failure mode dari suatu komponen atau sistem secara umum, secara matematis dapat diekspresikan di dalam persamaan (1). Gambar 1 menunjukkan hubungan antara state variable $X(t)$ dengan waktu kerusakan TTF.

$X(t)=1$; jika komponen beroperasi/hidup ..(1) dimana:

0 ; jika komponen gagal/rusak.

$X(t)=$ state variable yang mewakili kondisi failure mode pada waktu $t$

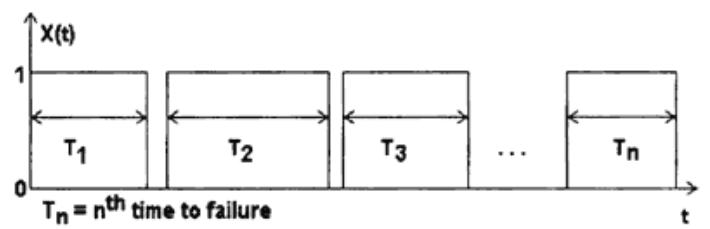

Gambar 1. Hubungan antara state variable X $(t)$ dengan waktu kerusakan TTF.

Waktu kerusakan, TTF, dari sebuah failure mode dapat mengikuti salah satu dari distribusidistribusi seperti: normal, eksponensial, Weibull, ataupun distribusi-distribusi lainnya.

Model kerusakan dapat ditentukan dengan mengumpulkan data-data kerusakan dari failure mode yang dianalisis. Ilustrasi dari data-data kerusakan sebuah failure mode dapat juga dilihat pada Gambar 1.

\subsection{Fungsi Distribusi Kumulatif (CDF) dan} Fungsi Kepadatan (PDF)

Dengan mengasumsikan bahwa TTF terdistribusi secara kontinu dengan fungsi kepadatan $f(t)$, maka probabilitas kegagalan failure mode dalam interval waktu $(0, \mathrm{t})$ dapat dinyatakan dengan persamaan berikut: $\mathrm{F}(\mathrm{t})=$

$\mathrm{P}(\mathrm{T} \leq \mathrm{t})=\int_{0}^{t} f(\xi) d \zeta$

dimana :

$\mathrm{F}(\mathrm{t})=$ fungsi distribusi kumulatif $(\mathrm{CDF})$ dari variabel acak TTF.

Fungsi $p d f$ dari variabel acak $T$ dapat ditentukan dari persamaan (2) dengan mengambil turunan dari $F(t)$ terhadap $t$ seperti ditunjukkan pada persamaan (3).

$$
\begin{aligned}
\mathrm{f}(\mathrm{t}) & =\frac{d}{d t} F(t)=\lim _{\Delta t \rightarrow 0} \frac{F(t+\Delta t)-F 9 t)}{\Delta t} \\
& =\lim _{\Delta t \rightarrow 0} \frac{P(t<T \leq t+\Delta t)}{\Delta t}
\end{aligned}
$$

\subsection{Fungsi Keandalan}

Fungsi keandalan merupakan fungsi yang mewakili probabilitas bahwa failure mode tidak menyebabkan kegagalan dalam interval waktu $(0, t]$ dan dinyatakan dengan persamaan berikut :

$\mathrm{R}(\mathrm{t})=1-\mathrm{F}(\mathrm{t})=\mathrm{P}(\mathrm{t}>\mathrm{t})=\int_{t}^{\infty} f(\zeta) d \zeta$

Persamaan (2) dapat juga disebut sebagai fungsi ketidakandalan dan dinyatakan dengan $\mathrm{Q}(\mathrm{t})$.

\subsection{Laju Kerusakan}

Laju kerusakan (conditional probability failure rate) adalah probabilitas bahwa sebuah kerusakan terjadi selama waktu tertentu namun kerusakan belum terjadi sebelum waktu tersebut. Oleh karena itu laju kerusakan memberikan informasi tambahan tentang usia pakai (survival life) dan digunakan untuk mengilustrasikan pola kerusakan.

Probabilitas sebuah failure mode akan menyebabkan kegagalan dalam interval waktu $(\mathrm{t}$ $+\Delta \mathrm{t}$ ), telah diketahui bahwa failure mode beroperasi pada waktu t, dapat ditentukan dengan persamaan berikut :

$$
\begin{aligned}
\mathrm{P}(\mathrm{t}<\mathrm{T} \leq \mathrm{t}+\Delta \mathrm{t}) & =\frac{P(t<T \leq t+\Delta t)}{P(T>t)} \\
& =\frac{F(t+\Delta t)-F(t)}{R(t)}
\end{aligned}
$$

Laju kerusakan, z (t), dari sebuah failure mode dapat diperoleh dengan membagi persamaan (5) dengan panjang interval waktu $\Delta \mathrm{t}$ dan $\Delta \mathrm{t} \rightarrow 0$.

$$
\begin{gathered}
z(t)=\lim _{\Delta t \rightarrow 0} \frac{P(t<T \leq t+\Delta t \mid T>t)}{\Delta t} \\
=\lim _{\Delta t \rightarrow 0} \frac{F(t+\Delta t)-F(t)}{\Delta t} \times \frac{1}{R(t)} \\
=\frac{f(t)}{R(t)}
\end{gathered}
$$

\subsection{Pola Kerusakan (Failure Pattern)}

Pemahaman bahwa failure mode peralatan dapat menunjukkan pola kerusakan berbeda memiliki implikasi penting dalam menentukan karakteristik suatu kerusakan. Gambar 2 menunjukkan karakteristik-karakteristik kerusakan tersebut. 


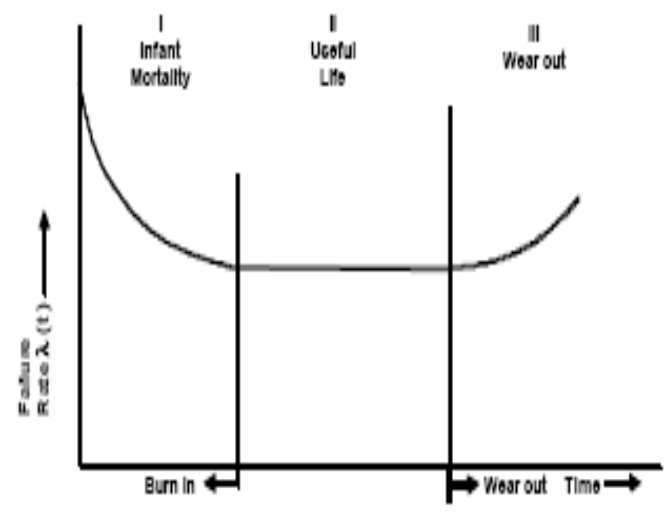

Gambar 2. Karakteristik-karakteristik kerusakan.

Karakteristik-karakteristik tersebut adalah:

- Wear-in Failure, yakni didominasi oleh perangkat-perangkat "lemah" (weak members) misalnya kesalahan proses manufaktur (manufacturing defect) dan salah pemasangan/perawatan (installation error). Karakteristik ini dikenal juga sebagai kerusakan burn in atau infant mortality.

- Random Failure, yakni didominasi oleh kerusakan yang tidak dapat diprediksi atau karena adanya suatu kesempatan/keadaan (chance failures). Karakteristik ini ditandai dengan laju kerusakan konstan dan distribusi kerusakan menunjukkan distribusi eksponensial.

- Wear-out Failure, yakni didominasi oleh masa akhir pakai peralatan. Karakteristik ini ditandai dengan meningkatnya laju kerusakan dan distribusi kerusakan menunjukkan distribusi Weibull.

Untuk menentukan jenis-jenis distribusi dari karakteristik kerusakan tersebut digunakan perangkat lunak Weibull++ 4.

\section{DISTRIBUSI PROBABILITAS}

Distribusi-distribusi probabilitas dapat bervariasi untuk menyatakan distribusi yang paling sesuai terhadap data-data kerusakan. Distribusi-distribusi probabilitas yang digunakan untuk memodelkan failure mode dari setiap kerusakan fungsional sistem penggerak motor diesel adalah distribusi normal, eksponensial, dan weibull.

Distribusi normal dipilih berdasarkan asumsi teorema central limit. Distribusi eksponensial dipilih berdasarkan karakteristik-karakteristiknya yang mewakili periode useful life. Sedangkan distribusi Weibull dipilih berdasarkan fleksibelitas dari parameter-parameternya dalam menentukan pola kerusakan dari data-data yang ada yang mungkin terletak pada periode useful life ataupun periode wear out.

\subsection{Distribusi Eksponensial}

Jika waktu kerusakan $\mathrm{T}$ dari sebuah failure mode terdistribusi secara eksponensial dengan parameter adalah $\lambda$ dan $\gamma$ maka fungsi pdf dari $T$ tersebut ditentukan dengan:

$\mathrm{f}(\mathrm{t})=\lambda \mathrm{e}^{-\lambda(\mathrm{t}-\gamma)}$

dimana :

$\lambda=$ laju kerusakan

$\gamma=$ parameter bentuk

Fungsi keandalan dari distribusi eksponensial menjadi :

$\mathrm{R}(\mathrm{t})=\mathrm{e}-\lambda(\mathrm{t}-\gamma)$

Sedangkan fungsi laju kerusakan distribusi eksponensial adalah:

$\mathrm{z}(\mathrm{t})=\lambda$

Persamaan (7) dikenal sebagai distribusi eksponensial dengan dua parameter. Distribusi eksponensial dengan satu parameter diperoleh jika $\gamma$ samadengan nol.

\subsection{Distribusi Weibull}

Distribusi Weibull merupakan salah satu dari distribusi yang paling banyak digunakan dibidang rekayasa keandalan. Hal ini dikarenakan distribusi tersebut memiliki kemampuan untuk memodelkan data-data yang berbeda dan banyak dengan pengaturan nilai parameter bentuk $\beta$. Fungsi pdf dari ketiga parameter distribusi Weibull dinyatakan dengan:

$f(t)=\frac{\beta}{\eta}\left(\frac{t-\gamma}{\eta}\right)^{\beta-1} e^{-\left(\frac{t-\gamma}{\eta}\right)^{\beta}}$

dimana :

$\beta=$ parameter bentuk, $\beta>0$

$\eta=$ parameter skala, $\eta>0$

$\gamma=$ parameter lokasi, $\gamma<$ waktu kerusakan pertama kali.

Fungsi keandalan distribusi Weibull dapat dinyatakan dengan:

$R(t)=e^{-\left(\frac{t-\gamma}{\eta}\right)^{\beta}}$

Dan laju kerusakan dapat dinyatakan dengan:

$z(t)=\frac{\beta}{\eta}\left(\frac{t-\gamma}{\eta}\right)^{\beta-1}$

Jika $\gamma=0$ maka diperoleh distribusi Weibull dengan dua parameter.

\subsection{Distribusi Normal}

Distribusi tipe kontinu ini merupakan distribusi yang sering digunakan dalam pengolahan data teknik. Variabel acak $T$ dinyatakan terdistribusi normal dengan rata-rata 
$\mu$ dan varian $\sigma^{2}, \mathrm{~T} \sim \mathrm{N}\left(\mu, \sigma^{2}\right)$ jika fungsi $p d f$ dari $\mathrm{T}$ adalah:

$$
f(t)=\frac{1}{\sigma \sqrt{2 \pi}} e^{-\frac{1}{2}\left(\frac{t-\mu}{\sigma}\right)}
$$

dimana :

$\sigma=$ deviasi standar dari variabel acak $\mathrm{T}$

$\mu=$ rata-rata dari variabel acak $\mathrm{T}$

Fungsi keandalan dari distribusi normal adalah:

$$
\begin{aligned}
R(t)=\int_{t}^{\infty} & \frac{1}{\sigma \sqrt{2 \pi}} e^{-\frac{1}{2}\left(\frac{t-\mu}{\sigma}\right)} d t \\
& =1-\Phi\left(\frac{t-\mu}{\sigma}\right)
\end{aligned}
$$

dimana :

$\Phi=$ fungsi CDF dari distribusi normal

Laju kerusakan dari distribusi normal dapat diperoleh dengan menggunakan persamaan (6).

\section{ANALISIS DATA}

Kapal-kapal yang dipilih adalah kapal-kapal perang jenis parchim, yang digunakan oleh TNI AL sebagai alat pertahanan di perairan Indonesia. Kapal-kapal tersebut dibangun pada tahun yang berbeda, yakni antara tahun 1981 hingga 1985.

Model kerusakan untuk masing-masing sistem penggerak motor diesel dinyatakan dalam salah satu dari distribusi probabilitas yakni distribusi normal, distribusi eksponensial dengan satu atau dua parameter, atau distribusi Weibull dengan dua atau tiga parameter.

Variabel masukan dari model kerusakan tersebut adalah variabel acak $\mathrm{T}$ yang mewakili waktu kerusakan dari mesin-mesin diesel tersebut. Kapal-kapal tersebut memiliki panjang $69 \mathrm{~m}$, lebar $8,95 \mathrm{~m}$, dan sarat 4,44 m.

Setiap kapal memiliki tiga unit mesin diesel sebagai pendorong utama. Masing-masing unit mesin diesel tersebut memiliki daya antara 2000 hp hingga 4000 hp. Mesin-mesin diesel tersebut merupakan mesin diesel empat langkah dengan putaran mesin berkisar antara $1000 \mathrm{rpm}$ hingga $2000 \mathrm{rpm}$ dan jumlah silinder sama-sama 16 buah.

Data-data kerusakan yang digunakan adalah data-data terbaru yang paling tidak berada pada interval dua buah overhaul. Tabel 1 menunjukkan periode pengumpulan data, jumlah kerusakan yang terjadi selama interval dua buah overhaul, dan laju kerusakan yang dihitung dengan rumus empiris yakni dengan membagi waktu operasi sistem penggerak motor diesel dengan jumlah kerusakan yang terjadi selama waktu operasi tersebut.
Data-data kerusakan yang digunakan adalah data-data terbaru yang paling tidak berada pada interval dua buah overhaul.

Tabel 1 menunjukkan periode pengumpulan data, jumlah kerusakan yang terjadi selama interval dua buah overhaul, dan laju kerusakan yang dihitung dengan rumus empiris yakni dengan membagi waktu operasi sistem penggerak motor diesel dengan jumlah kerusakan yang terjadi selama waktu operasi tersebut.

Gambar 3 menunjukkan perbandingan laju kerusakan mesin-mesin diesel yang dihitung dengan cara empiris. Besarnya jumlah kerusakan per hari berkisar antara 0.1008-0.2102.

Untuk sistem penggerak motor diesel pada kapal Lambung Mangkurat memiliki jumlah kerusakan per hari paling tinggi. Hal ini disebabkan sistem penggerak motor diesel tersebut telah terpasang sejak tahun 1982.

Failure mode dari setiap sistem penggerak motor diesel dikelompokkan menjadi beberapa kategori berdasarkan tingkat pengaruhnya terhadap sistem ataupun personil. Tabel 2 menunjukkan kategori-kategori kerusakan berdasarkan tingkat pengaruhnya terhadap sistem ataupun personil. Kerusakan-kerusakan yang dianalisa mengacu kepada Tabel 2 dan kerusakan-kerusakan yang dipilih adalah kerusakan-kerusakan dimana failure modefailuremodenya mempengaruhi kegagalan operasi sistem. Pada Tabel 3 ditunjukkan pengelompokkan failure mode berdasarkan frekuensi terjadinya. Keputusan yang akan diambil terhadap suatu failure mode ditentukan terlebih dahulu dengan membuat suatu risk matrix seperti yang ditunjukkan pada Tabel 4 . Kategori-kategori keputusan yang diambil terhadap suatu failure mode dapat dikelompokkan seperti pada Tabel 5.

Data-data kerusakan TTF dari masing-masing failure mode untuk semua sistem penggerak motor diesel pada setiap kapal tersebut dimodelkan dalam semua distribusi data yang telah disebutkan di atas. Parameter-parameter untuk masing-masing distribusi ditentukan dengan bantuan perangkat lunak Weibull ++4 untuk mempercepat perhitungan dari parameterparameter tersebut. Distribusi-distribusi yang diperoleh dari data-data kerusakan tersebut kemudian dibandingkan untuk memilih jenis distribusi yang paling sesuai. Distribusi-distribusi terbaik untuk masing-masing failure mode yang terpilih dari semua sistem penggerak motor diesel tersebut diperoleh berdasarkan algoritma perhitungan yang dimiliki oleh perangkat lunak Weibull ++4 . 
Tabel 1. Periode pengumpulan data.

\begin{tabular}{|c|c|c|c|c|c|c|}
\hline No & Ship & Initial & Last & $\begin{array}{l}\text { Duration } \\
\text { (days) }\end{array}$ & $\begin{array}{c}\text { No.of } \\
\text { failure }\end{array}$ & Failure/day \\
\hline 1 & IMAM BONJOL & $\begin{array}{c}\text { 2Januari } \\
2003 \\
\end{array}$ & $\begin{array}{c}26 \\
\text { Desember } \\
2004 \\
\end{array}$ & 724 & 73 & 0.100828729 \\
\hline 2 & $\begin{array}{l}\text { CUT NYAK } \\
\text { DHIEN }\end{array}$ & $\begin{array}{l}4 \text { Januari } \\
2004 \\
\end{array}$ & $\begin{array}{c}29 \\
\text { Desember } \\
2005 \\
\end{array}$ & 725 & 98 & 0.135172414 \\
\hline 3 & TEUKU UMAR & $\begin{array}{c}06 \\
\text { September } \\
2003\end{array}$ & $\begin{array}{c}27 \\
\text { Agustus } \\
2004\end{array}$ & 720 & 130 & 0.180555556 \\
\hline 4 & $\begin{array}{l}\text { SUTEDI SENA } \\
\text { PUTRA }\end{array}$ & $\begin{array}{c}13 \text { Maret } \\
2003\end{array}$ & $\begin{array}{c}25 \\
\text { Februari } \\
2004\end{array}$ & 714 & 105 & 0.147058824 \\
\hline 5 & SUTANTO & $\begin{array}{l}25 \text { Februari } \\
2003\end{array}$ & $\begin{array}{c}15 \\
\text { Februari } \\
2004 \\
\end{array}$ & 718 & 90 & 0.125348189 \\
\hline 6 & $\begin{array}{l}\text { SULTAN } \\
\text { THAHA } \\
\text { SYAIFUDDIN }\end{array}$ & $\begin{array}{l}19 \text { Agustus } \\
2004\end{array}$ & $\begin{array}{c}1 \text { Agustus } \\
2005\end{array}$ & 712 & 123 & 0.172752809 \\
\hline 7 & $\begin{array}{l}\text { SILAS } \\
\text { PAPARE }\end{array}$ & 21 Juli 2004 & 5 Juli 2005 & 719 & 143 & 0.198887344 \\
\hline 8 & $\begin{array}{l}\text { MEMET } \\
\text { SASTRAWIRIA }\end{array}$ & $\begin{array}{c}1 \text { Maret } \\
2004\end{array}$ & $\begin{array}{c}21 \\
\text { Februari } \\
2005 \\
\end{array}$ & 722 & 111 & 0.153739612 \\
\hline 9 & $\begin{array}{l}\text { KAPITAN } \\
\text { PATTIMURA }\end{array}$ & $\begin{array}{l}2 \text { Februari } \\
2004\end{array}$ & $\begin{array}{l}29 \text { Januari } \\
2005 \\
\end{array}$ & 726 & 117 & 0.161157025 \\
\hline 10 & HASAN BASRI & $\begin{array}{l}27 \text { Januari } \\
2004\end{array}$ & $\begin{array}{l}10 \text { Januari } \\
2005\end{array}$ & 713 & 136 & 0.190743338 \\
\hline 11 & PATI UNUS & $\begin{array}{l}19 \text { Februari } \\
2003 \\
\end{array}$ & $\begin{array}{c}5 \text { Februari } \\
2004 \\
\end{array}$ & 716 & 131 & 0.182960894 \\
\hline 12 & $\begin{array}{l}\text { UNTUNG } \\
\text { SURAPATI }\end{array}$ & $\begin{array}{c}21 \\
\text { Januari2003 }\end{array}$ & $\begin{array}{l}23 \text { Januari } \\
2004\end{array}$ & 732 & 114 & 0.155737705 \\
\hline 13 & $\begin{array}{l}\text { LAMBUNG } \\
\text { MANGKURAT }\end{array}$ & $\begin{array}{c}12 \text { Maret } \\
2003\end{array}$ & $\begin{array}{c}5 \text { Maret } \\
2004 \\
\end{array}$ & 723 & 152 & 0.210235131 \\
\hline 14 & NUKU & $\begin{array}{c}15 \\
\text { September } \\
2003\end{array}$ & $\begin{array}{c}05 \\
\text { September } \\
2004\end{array}$ & 720 & 146 & 0.202777778 \\
\hline 15 & TJIPTADI & $\begin{array}{c}05 \\
\text { September } \\
2003 \\
\end{array}$ & $\begin{array}{c}25 \\
\text { Agustus } \\
2004 \\
\end{array}$ & 719 & 131 & 0.182197497 \\
\hline 16 & WIRATNO & $\begin{array}{c}10 \\
\text { September } \\
2004 \\
\end{array}$ & $\begin{array}{c}25 \\
\text { Agustus } \\
2005 \\
\end{array}$ & 714 & 102 & 0.142857143 \\
\hline
\end{tabular}

Tabel 2. Konsekuensi dari kategori kerusakan.

\begin{tabular}{|c|l|}
\hline \multicolumn{2}{|c|}{ Severity of Consequence } \\
\hline Kategori & \multicolumn{1}{c|}{ Definisi } \\
\hline Catastrophic (I) & $\begin{array}{l}\text { Menyebabkan kematian personel atau } \\
\text { sistem shutdown }\end{array}$ \\
\hline Critical (II) & $\begin{array}{l}\text { Cedera parah/cacat atau sistem tidak } \\
\text { dapat berfungsi sesuai dengan yang } \\
\text { ditentukan }\end{array}$ \\
\hline Marginal (III) & $\begin{array}{l}\text { Cedera ringan atau sistem mengalami } \\
\text { penurunan fungsi kinerja }\end{array}$ \\
\hline Negligible (IV) & $\begin{array}{l}\text { Cedera sangat ringan atau sistem dapat } \\
\text { berfungsi dengan resiko kecil }\end{array}$ \\
\hline
\end{tabular}

Tabel 3. Frekuensi dari kerusakan.

\begin{tabular}{|l|l|l|}
\hline \multicolumn{3}{|c|}{ Severity of Frequency } \\
\hline \multirow{2}{*}{ Frekuensi kejadian } & \multicolumn{1}{|c|}{ Definisi } \\
\cline { 2 - 2 } & \multicolumn{1}{|c|}{ Kualitatif } & Kuantitatif \\
\hline Frequent & Sering terjadi & $\geq 1 \times 10^{-3}$ \\
\cline { 1 - 2 } Probable & $\begin{array}{l}\text { Sangat mungkin } \\
\text { terjadi }\end{array}$ & $\geq 1 \times 10^{-4}$ \\
\cline { 1 - 2 } Occasional & Umum terjadi & $\geq 1 \times 10^{-5}$ \\
\cline { 1 - 2 } Remote & Jarang terjadi & $\geq 1 \times 10^{-6}$ \\
\cline { 1 - 2 } Improbable & $\begin{array}{l}\text { Tidak mungkin } \\
\text { terjadi }\end{array}$ & $<1 \times 10^{-6}$ \\
\hline
\end{tabular}

Tabel 4. Matriks Resiko (Risk).

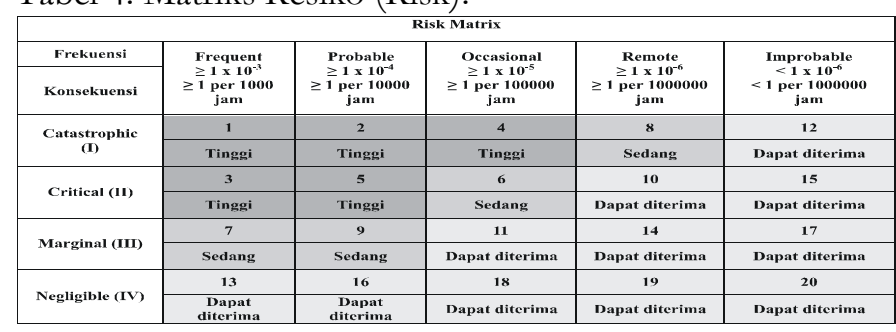

Tabel 5. Perhitungan Risiko (Risk).

\begin{tabular}{|c|c|}
\hline \multicolumn{2}{|c|}{ Rating of Risk } \\
\hline Rating & Definisi \\
\hline Tinggi (high) & $\begin{array}{c}\text { Memerlukan perbaikan untuk } \\
\text { mengeliminasi bahaya atau } \\
\text { pemeriksaan }\end{array}$ \\
\hline Sedang (medium) & $\begin{array}{c}\text { Memerlukan tinjauan ulang } \\
\text { terhadap dapat diterimanya } \\
\text { resiko }\end{array}$ \\
\hline $\begin{array}{c}\text { Dapat diterima } \\
\text { (accept) }\end{array}$ & $\begin{array}{c}\text { Resiko yang dapat diterima } \\
\text { ditinjau sebagai rancangan } \\
\text { yang sudah matang }\end{array}$ \\
\hline
\end{tabular}




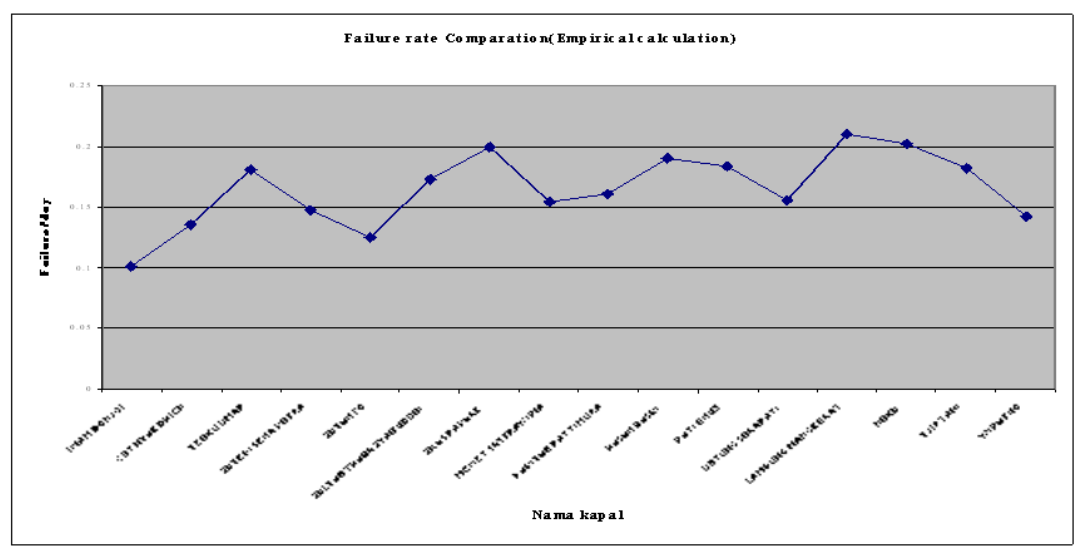

Gambar 3. Perbandingan jumlah kerusakan per hari.

Tabel 6 menunjukkan nilai dari parameterparameter distribusi yang mewakili masingmasing data TTF sistem penggerak motor diesel pada setiap kapal. Berdasarkan tabel tersebut dapat terlihat bahwa terdapat sembilan puluh sembilan model failure mode dari setiap sistem penggerak motor diesel untuk masing-masing kapal memiliki distribusi Weibull dua atau tiga parameter, sebanyak delapan model berdistribusi normal dan sebanyak lima model lainnya memiliki distribusi eksponensial.

Pada dasarnya, pengeplotan kurva laju kerusakan berdasarkan persamaan (6). Untuk sejumlah data yang memiliki distribusi Weibull dua atau tiga parameter, persamaan (12) dapat digunakan untuk mengeplot laju kerusakan. Data-data yang memiliki distribusi normal, persamaan (6) dapat digunakan dengan menghitung terlebih dahulu nilai pdf dan keandalan pada waktu tertentu. Sedangkan datadata yang berdistribusi eksponensial satu atau dua parameter, persamaan (9) dapat digunakan untuk mengeplot laju kerusakan.

Gambar 4 menunjukkan perbandingan laju kerusakan dari masing-masing sistem penggerak motor diesel pada setiap kapal untuk ketujuh failure mode yang diplotkan kedalam satu bidang kurva. Berdasarkan kurva tersebut dapat terlihat bahwa untuk jam operasi yang diuji, failure mode-failure mode dari masing-masing sistem penggerak motor diesel untuk setiap kapal memiliki frekuensi kejadian yang berbeda-beda.

Tabel 7 menunjukkan frekuensi kejadian masing-masing failure mode untuk setiap kapal. Berdasarkan Tabel 7, failure mode yang sering terjadi (frequent) terdapat sebanyak tiga kali, yakni failure mode pertama pada kapal Tjiptadi dan failure mode ketujuh pada kapal Imam Bonjol dan Sutanto. Sedangkan failure mode yang umum terjadi (occasional) terdapat sebanyak tiga belas kali, yakni failure mode pertama pada kapal Cut Nyak Dhien, Sutedi
Sena Putra, Sutanto, Kapitan Pattimura; failure mode kedua pada kapal Silas Papare, Memet Sastrawiria, Tjiptadi; failure mode ketiga pada kapal Tjiptadi; failure mode keempat pada kapal Sutedi Sena Putra dan Memet Sastrawiria; failure mode kelima pada kapal Silas Papare dan Memet Sastrawiria; dan failure mode keenam pada kapal Silas Papare. Failure mode yang sangat mungkin terjadi terdapat hampir pada semua kapal kecuali yang telah disebutkan diatas. Penentuan peringkat resiko dari masing-masing failure mode pada setiap kapal mengacu kepada Tabel 4. Berdasarkan Tabel 4 dapat diketahui bahwa tingkat resiko dari keseluruhan failure mode yang dianalisa berada pada tingkat resiko yang tinggi. Hal ini disebabkan oleh pemilihan failure mode yang dianalisis berdasarkan kategori catastrophic yakni menyebabkan kematian atau sistem shutdown serta laju kerusakan yang sering, sangat mungkin, dan umum terjadi pada kapalkapal tersebut. Faktor usia sistem penggerak motor diesel baik dari sisi kapal maupun motor diesel dan sistem pendukung motor diesel yang digunakan sangat berpengaruh terhadap tingginya tingkat resiko pada sistem penggerak motor diesel pada kapal-kapal yang telah dianalisa. Faktor-faktor tersebut menunjukkan bahwa sistem penggerak motor diesel pada setiap kapal perang jenis parchim yang telah dianalisa memiliki karakteristik-karateristik periode wear out baik itu baru mulai memasuki periode wear out maupun telah berada pada periode wear out. Faktor-faktor tersebut juga dapat menunjukkan bahwa sebagian komponen ataupun peralatan telah memasuki masa akhir pemakaian sehingga program perawatan yang dilakukan terhadap sistem penggerak motor diesel tersebut harus dievaluasi keefektifannya. 
Tabel 6. Nilai dari parameter-parameter distribusi.

\begin{tabular}{|c|c|c|c|c|c|c|c|c|c|}
\hline ive Mode & & \multirow{2}{*}{ 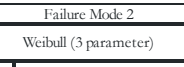 } & \multirow{2}{*}{\multicolumn{2}{|c|}{\begin{tabular}{|c|} 
Faillure Mode 3 \\
Weibull( 3 parameter)
\end{tabular}}} & \multicolumn{2}{|c|}{ 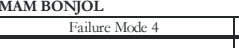 } & \multirow{2}{*}{ 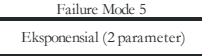 } & \multirow{2}{*}{ 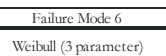 } & \multirow{2}{*}{$\begin{array}{l}\text { Falulur Mode } 7 \\
\text { Wetul (3parameter) }\end{array}$} \\
\hline lisnis & 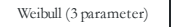 & & & & & (3) parameter) & & & \\
\hline Parameter & 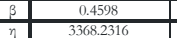 & $\frac{1.447}{52778999}$ & $\frac{\beta}{n}$ & $\frac{0.0777}{4324651}$ & $\frac{\beta}{n}$ & $\frac{1.09}{4092.2}$ & $\begin{array}{ll}\lambda & \\
y & \end{array}$ & \begin{tabular}{c|c}
$\beta$ & 0.3212 \\
$n$
\end{tabular} & \begin{tabular}{l|l}
$\beta$ & 0.80121 \\
$n$ & 481602
\end{tabular} \\
\hline & 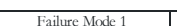 & Lire varde 2 & & & & & & & \\
\hline $\begin{array}{c}\text { Jisnis } \\
\text { Distribusi } \\
\end{array}$ & Weibull (3 parameter) & Weibull ( 3 parameter) & Weitull & 3 parameterer) & & (3 pratameter) & 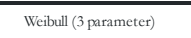 & 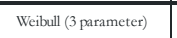 & Weibull (3 pa a rameter) \\
\hline Parameter & 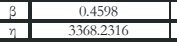 & $\begin{array}{l}\frac{0.5436}{42525} \\
\end{array}$ & $\frac{\beta}{\eta}$ & . 0.4668 & 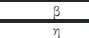 & $\frac{0.7211}{445203}$ & $\frac{1.7656}{6.121155}$ & $\quad 0.080$ & 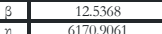 \\
\hline & & & & & & & & & \\
\hline $\begin{array}{l}\text { Fallue Mode } \\
\text { Filu Mold }\end{array}$ & Failure Mdede1 & Filulue Node & & NNoded & & & 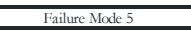 & Inere & aillur \\
\hline 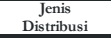 & Weitull (2 parameter) & Elsponenenail (2parameter) & Welaull & 3 parametert) & & $(3$ pramancter $)$ & Weibull (3 parameter) & Weituall (2 parameter) & Weibull (3 parameter) \\
\hline Parameter & \begin{tabular}{|l|l} 
& 0.7716 \\
& 876.8468 \\
\end{tabular} & $\begin{array}{l}0.0003 \\
.302273 \\
-3273\end{array}$ & $\frac{\beta}{\eta}$ & $\begin{array}{l}0.0919 \\
3521.6633 \\
\end{array}$ & $\frac{\beta}{n}$ & $\begin{array}{l}1.1 .16 \\
715252509 \\
\end{array}$ & \begin{tabular}{l|l}
$\beta$ & 34946 \\
$\eta$ & 1457.2012 \\
\end{tabular} & \begin{tabular}{l|l}
3 & 0.6678 \\
$n$ & 544,4286 \\
\end{tabular} & \begin{tabular}{l|l} 
& 1.3196 \\
$n$ & 9645.4004
\end{tabular} \\
\hline & & & & 2.46649 & $y$ & 45237 & .7014.14074 & & .35292974 \\
\hline & Falure $\mathrm{M}$ & & Failu & cinded & 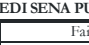 & 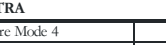 & & & \\
\hline $\begin{array}{l}\text { Jenis } \\
\text { Distribusi }\end{array}$ & 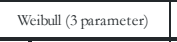 & Witalul (sparametere) & Wectuall & 3 parameterer) & & tormal & Weibull (3 parameter) & 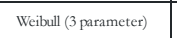 & Weibull (3 parameter) \\
\hline Parameter & 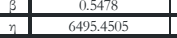 & $\frac{0.8507}{51343259}$ & & 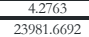 & & $\frac{3277.32}{6203666}$ & 51986 & $E_{-1}$ & 9.955 \\
\hline ire Modd & Fallue Mode 1 , & 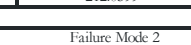 & & Falluec & $\begin{array}{c}\text { SUTANTO } \\
3\end{array}$ & & & - & Finum \\
\hline 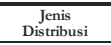 & Weitulul( 3 parameter) & Witall (3parametere) & & Weitiul $(3 \mathrm{pm}$ & & Weitulul( 3 parameter) & 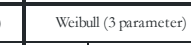 & 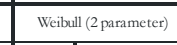 & Weitull (3param \\
\hline Parameter & 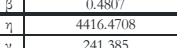 & 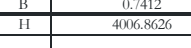 & & & & 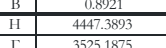 & 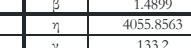 & 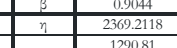 & 等 \\
\hline Filure Mode & Finiture Nodel 1 & re MNde 2 & & 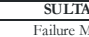 & $\begin{array}{ll}\text { THAHA: } \\
c 3\end{array}$ & ODDIN & Failure Mole 5 & Failure Mode 6 & Failure Mode \\
\hline $\begin{array}{c}\text { Jenis } \\
\text { Distribusi }\end{array}$ & Weituall (3 parameter) & Wétalul (sparametere) & & Weitul $(3 \mathrm{PPA}$ & & Weilbull (3 parameter) & 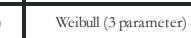 & Weiculul (2paramecter) & Witalul (2) pram \\
\hline Parameter & $\begin{array}{l}\frac{5.0432}{\beta} \\
\eta \\
1061.6558\end{array}$ & 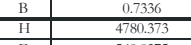 & & & 8. 1.525 & \begin{tabular}{c|c}
$\mathrm{B}$ & 1.543 \\
$\mathrm{H}$ & 7930.0185 \\
\end{tabular} & \begin{tabular}{l|l}
$\beta$ & 0.9646 \\
$n$ & 5136238 \\
\end{tabular} & \begin{tabular}{l|l}
$\beta$ & 1.1229 \\
$n$ & 7140.27 \\
\end{tabular} & 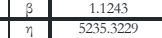 \\
\hline & Fáalure Molect & Failure Modc 2. & & Faiture $\mathrm{M}$ & 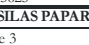 & Faillure Modc 4 & Fialure Mode 5 & Faillue Mode 6 & Fialuec Macte \\
\hline $\begin{array}{c}\text { Jenis } \\
\text { Distitiusi }\end{array}$ & Wecibull (2parameter) & Weitall (2parametecer) & & Wectioul $(3 \mathrm{pm}$ & & Weitull (3p parameter) & $\begin{array}{l}\text { Nomal } \\
\text { Nomate }\end{array}$ & Normal & Weiluall (3p param \\
\hline Parameter & 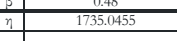 & $\frac{B}{H}$ & & & & 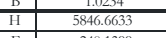 & $\frac{302825}{8014214}$ & $\frac{\pi}{\mu}$ & $n$ \\
\hline & 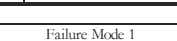 & Fillure Mode 2 & & & 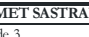 & RiA & Node 5 & (Nate 6 & - \\
\hline & 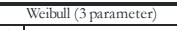 & 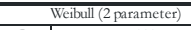 & & & & Normal & Normal & 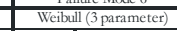 & s \\
\hline Parameter & \begin{tabular}{l|l} 
& 1.02043 \\
$\eta$ & 738.9053 \\
\end{tabular} & $\frac{0.5554}{3893,4652}$ & $\frac{\beta}{n}$ & & 每3 & 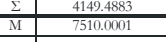 & \begin{tabular}{l|l}
$\sigma$ & 587.7117 \\
$\mu$ & 6388.8333 \\
\end{tabular} & $\begin{array}{ll}0.6333 \\
370.2994\end{array}$ & $\frac{\beta}{\eta}$ \\
\hline 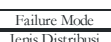 & & Salue naver & & & & 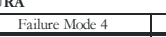 & Fallue Made s & Moxer & Failure Modc 7 \\
\hline mis Distroust & 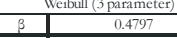 & 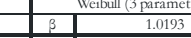 & 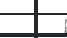 & Bctifut & & 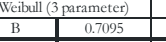 & 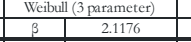 & 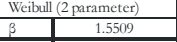 & 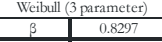 \\
\hline Parameter & \begin{tabular}{l|l}
$n$ & 3343.0752
\end{tabular} & & & & & & 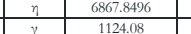 & 1 & \begin{tabular}{l|l}
$n$ & 4732.7 \\
$y$ & 26.49 \\
\end{tabular} \\
\hline
\end{tabular}
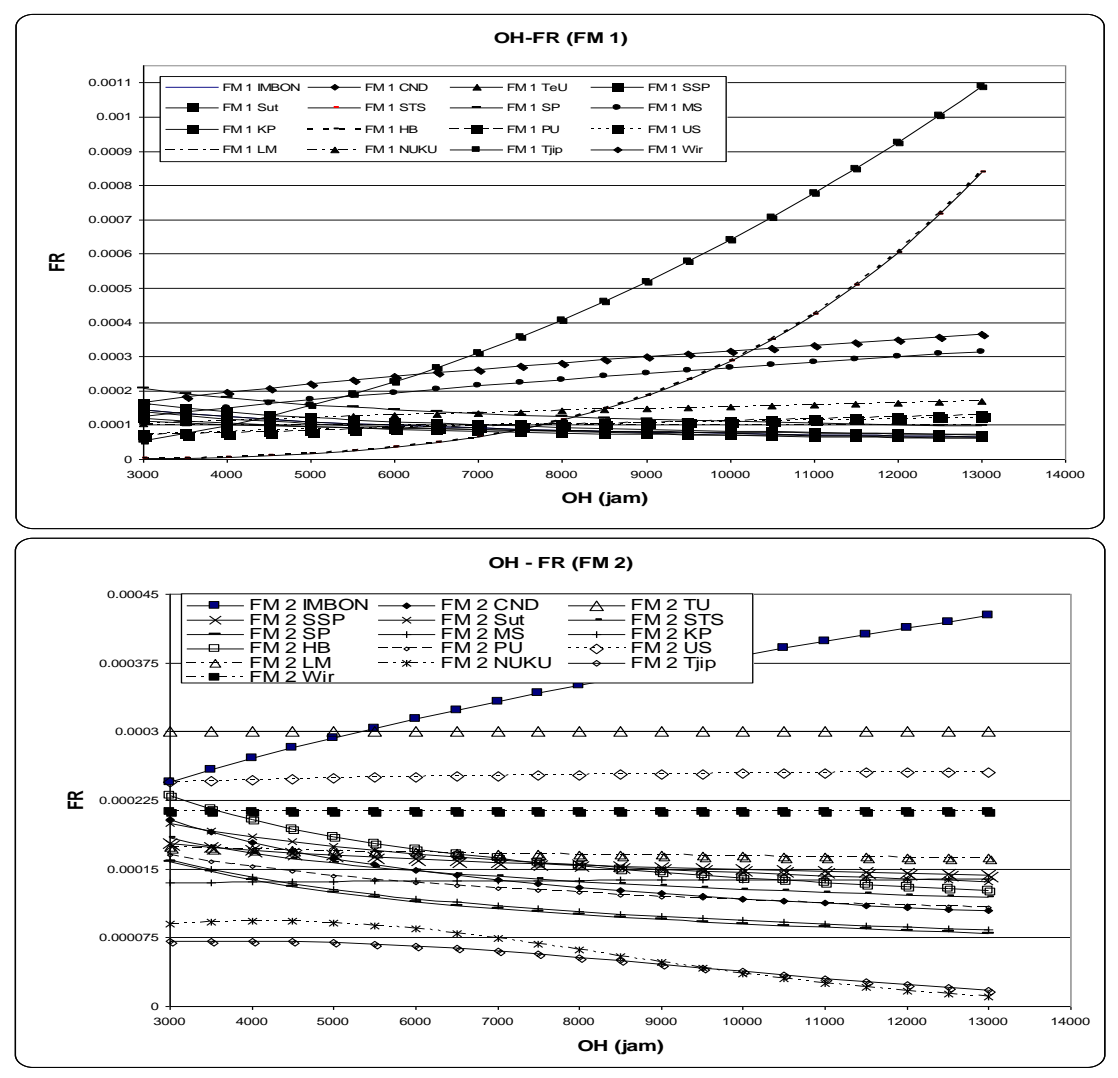

Vol. 18, No. 1, Februari 2007 - Majalah IPTEK 

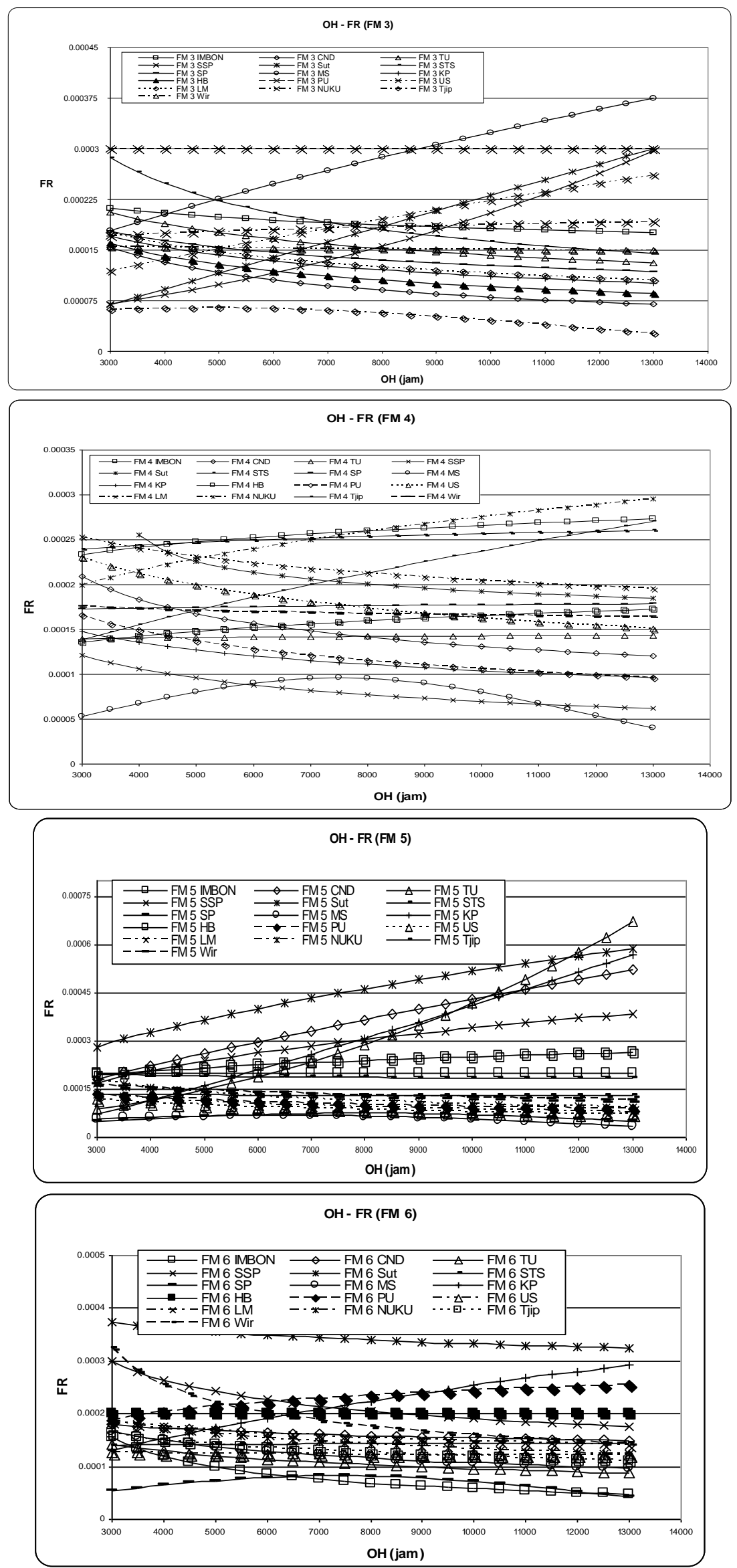


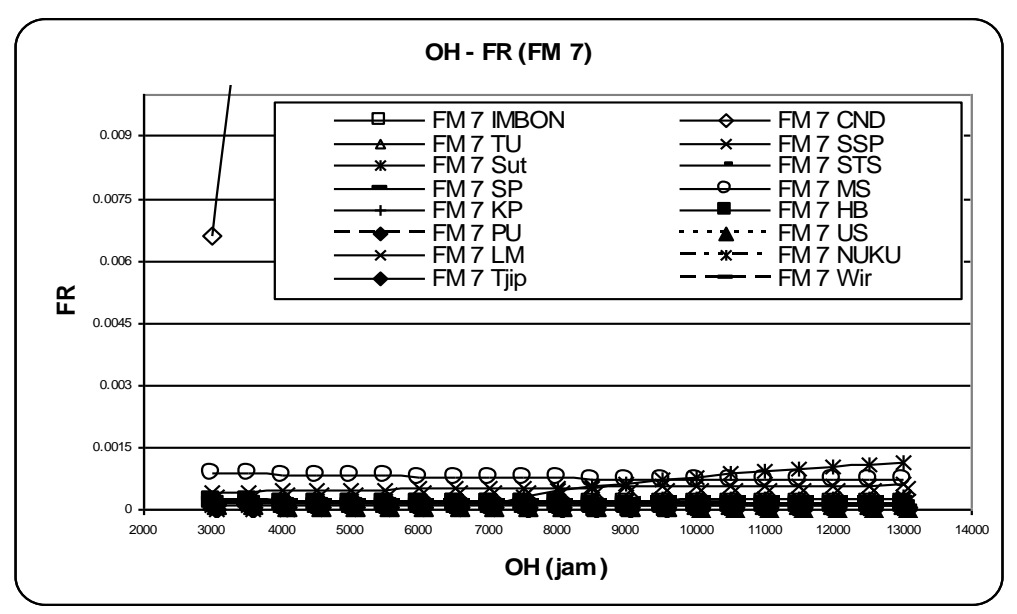

Gambar 4. Perbandingan masing-masing failure mode pada semua kapal.

Tabel 7. Frekuensi kejadian masing-masing failure mode untuk setiap kapal.

\begin{tabular}{|c|c|c|c|c|c|c|c|c|}
\hline NO & Nama Kapal & Failure Mode 1 & Failure Mode 2 & Failure Mode 3 & Failure Mode 4 & Failure Mode 5 & Failure Mode 6 & Failure Mode 7 \\
\hline 1 & IMAM BONJOL & Probable & Probable & Probable & Probable & Probable & Probable & Frequent \\
\hline 2 & CUT NYAK DHIEN & Occasional & Probable & Probable & Probable & Probable & Probable & Probable \\
\hline 3 & TEUKU UMAR & Probable & Probable & Probable & Probable & Probable & Probable & Probable \\
\hline 4 & SUTEDI SENA PUTRA & Occasional & Probable & Probable & Occasional & Probable & Probable & Probable \\
\hline 5 & SUTANTO & Occasional & Probable & Probable & Probable & Probable & Probable & Frequent \\
\hline 6 & SULTAN THAHA SYAIFUDDIN & Probable & Probable & Probable & Probable & Probable & Probable & Probable \\
\hline 7 & SILAS PAPARE & Probable & Occasional & Probable & Probable & Occasional & Occasional & Probable \\
\hline 8 & MEMET SASTRAWIRIA & Probable & Occasional & Probable & Occasional & Occasional & Probable & Probable \\
\hline 9 & KAPITAN PATTIMURA & Occasional & Probable & Probable & Probable & Probable & Probable & Probable \\
\hline 10 & HASAN BASRI & Probable & Probable & Probable & Probable & Probable & Probable & Probable \\
\hline 11 & PATI UNUS & Probable & Probable & Probable & Probable & Probable & Probable & Probable \\
\hline 12 & UNTUNG SURAPATI & Probable & Probable & Probable & Probable & Probable & Probable & Probable \\
\hline 13 & LAMBUNG MANGKURAT & Probable & Probable & Probable & Probable & Probable & Probable & Probable \\
\hline 14 & NUKU & Probable & Probable & Probable & Probable & Probable & Probable & Probable \\
\hline 15 & TJIPTADI & Frequent & Occasional & Occasional & Probable & Probable & Probable & Probable \\
\hline 16 & WIRATNO & Probable & Probable & Probable & Probable & Probable & Probable & Probable \\
\hline
\end{tabular}

\section{SIMPULAN}

Paper ini telah membahas analisis laju kerusakan berdasarkan failure mode dari enam belas unit sistem penggerak motor diesel yang terpisah untuk menggerakkan kapal perang jenis parchim.

Berdasarkan analisis yang telah dilakukan terhadap failure mode paling kritis dari masingmasing kapal perang jenis parchim tersebut, dapat diketahui bahwa sistem penggerak motor diesel pada kapal-kapal tersebut memiliki karakteristik-karakteristik wear-out dengan tingkat resiko yang tinggi. Hal ini dapat dijadikan acuan dasar dalam pengambilan keputusan sebagai proses lanjut. Analisis lanjut yang diperlukan adalah penentuan penggantian komponen ataupun peralatan dari sistem penggerak motor diesel tersebut yang berkaitan dengan metode perawatan yang digunakan, interval perawatan, jumlah perawatan yang dilakukan, dsb. Sangat disarankan untuk menggunakan analisis RCM yang acceptable dan sustainable.

\section{DAFTAR ACUAN}

Artana, K.B. (2003), 'Penjadwalan dan Penentuan Lokasi Perawatan Optimum Sistem Permesinan di Kapal', Jurnal Tekno. Kelautan, Vol. 7.

Conachey, R.M. dan Montgomery, R.L. (2003), 'Application of Reliability-centered Maintenance Techniques to The Marine Industry', SNAME, Texas.

Dismatal, S. (2005), Sistem Pemeliharaan Terencana (Planned Maintenance System), Mabesal., Rancangan Postur TNI AL tahun 2005-2024.

Mabesal, (2004), Data Teknis Kelas Parchim. Masroeri, A.A., Priyanta, D. dan Artana, K.B. (2000), 'Failure Rate Analysis of $1000 \mathrm{hp}$ Main Engines Installed on Small General Cargo Ships : a Proof of Wear-Out Period of Installed Main Engines', Proceedings of Sixth International Syposium on Marine Engineering (ISME), Vol. 2. 
Moubray, J. (1997), Reliability-centered Maintenance, Industrial Press Inc., New York.

NAVAIR 00-25-403 (2001), Guidelines for the Naval Aviation Reliability-Centered Maintenance Process, Direction of Commander, Naval Air Systems Command.
Walpole, R.E. (1993), Pengantar Statistika, PT. Gramedia Pustaka Utama, Jakarta.

Diterima: 06 September 2006

Disetujui untuk diterbitkan: 08 Februari 2007 